\title{
The Genetics of Locomotor Disorders
}

\section{O. Carter and T. J. Fairbank}

The authors of this book have two objectives in view: first to provide a useful source of information to doctors, and orthopaedic surgeons in particular, whose work requires some knowledge of the genetic factors affecting locomotor diseases, and secondly to offer a reference source to those working in genetics itself. For each disorder a clinical definition and description is given, followed by the genetic aspects and a full list of references. £5 Oxford Monographs on Medical Genetics

\section{The Distribution of the Human Blood Groups}

\section{and other Biochemical Polymorphisms}

\section{A. E. Mourant, Ada C. Kopéc, and Kazimiera Domaniewska-Sobczak}

The first edition of this book was published in 1954 when only ten major genetically independent systems of blood groups had been discovered. Now completely rewritten and expanded to include a mass of new information, this second edition is a unique compendium of the basic quantitative data on human population genetics. As such it will be needed by every research worker in physical anthropology and in human genetics. Second edition £35 Oxford Monographs on Medical Genetics

\section{The Biology of Tribolium with Special Emphasis on Genetic Aspects}

\section{Volume II}

\section{A. Sokoloff}

Flour beetles of the genus Tribolium are primary pests of stored products. Because of their economic importance, and the ease of handling in the laboratory, they are widely used by entomologists, population ecologists, and geneticists. This volume brings together widely scattered information on Tribolium ecology. It also has a chapter on physiological and biochemical studies, as well as one on mathematical models relating to population ecology. Illustrated $£ 19.50$

\section{Our Future Inheritance}

\section{Choice or Chance?}

\section{Alun Jones and Walter F. Bodmer}

Recent advances in genetics, biology, and medicine have important social, ethical, and legal implications as well as being of great scientific interest. This book is concerned with some of the most significant topics: artificial insemination and fertilization of humans; genetic screening and selective abortion; organ transplantation; genetic engineering and cloning. $£ 4$ paper covers $£ 1.25$

\section{Oxford University Press}




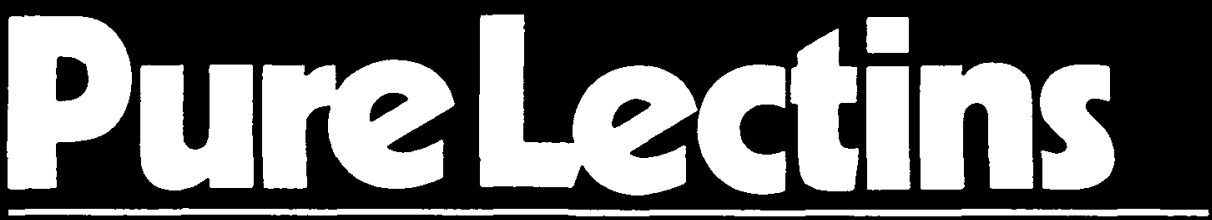

Cellsurface studies Lymphocyte stimulation Chromosome analysis

\section{Leucoagglutinin}

Unilike crude preparations of PHA,

Leucoagglutinin is an electrophoretically pure glycoprotein with potent lymphocyte

stimulating activity but no

erythroagglutinating activity.

\section{ConA}

Prepared by allinity chromalography on Sephadex. Fully active and no further purification is required. Freeze-dried powder containing at least $99 \%$ protein and less than $0.1 \%$ carbohydrate. 


\section{GENETICAL}

\section{RESEARCH}

EDITORIAL BOARD

C. H. WADDINGTON (Chairman)

CHARLOTTE AUERBACH W. HAYES

R.H. PRITCHARD MARYF.LYON R. RILEY A. ROBERTSON

EXEOUTIVE EDITOR

E. C. R. REEVE

ASSISTANT EXEOUTIVE EDITOR

N. S. WILLETTS

\section{Volume 25. 1975}

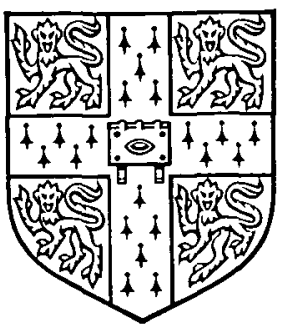

CAMBRIDGE

AT THE UNIVERSITY PRESS 
PUBLISHED BY

THE SYNDICS OF THE CAMBRIDGE UNIVERSTTY PRESS

Bentley House, 200 Euston Road, London NW1 2DB

American Branch: 32 East 57th Street, New York, N.Y. 10022

(C) Cambridge University Press, 1975

Printed in Areat Britain at the University Printing House, Cambridge 


\section{CONTENTS}

No. 1 (February 1975)

Hoekstra, Rolf F. A deterministic model of cyclical selection

Ruano, R. G., Orozco, F. and López-Fanjul, C. The effect of different selection intensities on selection response in egg-laying of Tribolium castaneum

Srivastava, Sheela and Sinha, Umarkant. Six new loci controlling resistance to $p$-fluorophenylalanine in Aspergillus nidulans

Greenberg, Joseph, Donch, JoHn and Berends, Leonard. The dominance of $\operatorname{exr} B$ over exrB $B^{+}$in heterodiploids of Escherichia coli

Garnett, I. and Falconer, D. S. Protein variation in strains of mice differing in body size

Celis, Esteban, Mas, Jame and Brunner, Aurora. Nuclear and cytoplasmic cross-resistance and correlated sensitivity to DNA intercalating drugs in a petite-negative yeast

Day, Martin, Potts, J. Rowland and Clarke, Patricta H. Location of genes for the utilization of acetamide, histidine and proline on the chromosome of Pseudomonas aeruginosa

Short Papers

Clayton, R. M. Failure of growth regulation of the lens epithelium in strain of fast-growing chicks

McLaren, Anne. The independence of germ-cell genotype from somatic influence in chimaeric mice

No. 2 (April 1975)

Pollak, Edward and ARnold, Barry C. On sojourn times at particular gene frequencies

Senathirajah, S. and Lewis, D. Resistance to amino acid analogues in Coprinus: Dominance modifier genes and dominance reversal in dikaryons and diploids

Greenberg, Joseph, Berends, Leonard, Donch, John and Johnson, BEN. Peversion studies with exrB in Escherichia coli

Polknghorne, Meryl and Hynes, M. J. Mutants affecting histidine utilization in Aspergillus nidulans 
Brown, A. H. D., Marshall, D. R. and Albrecht, L. Profiles of electrophoretic alleles in natural populations

Avery, P. J. Extensions to the model of an infinite number of selectively neutral alleles in a finite population

BeLCOUR, LÉon. Cytoplasmic mutations isolated from protoplasts of Podospora anserina

WooDRUFF, R. C. The control of mutational instability by a new mutator gene of Drosophila melanogaster

Carey, K. E. and Krishnapillai, V. Chromosomal location of prophage J51 in Pseudomonas aeruginosa strain PAO

Short PAPERS

Sharma, T. and Garg, G. S. Constitutive heterochromatin and karyotype variation in Indian pygmy mouse, Mus dunni

Cachetro, N. L. A. and Russell, Liane B. Evidence that Linkage Group IV as well as Linkage Group $\mathrm{X}$ of the mouse are in chromosome 10

Sved, J.A. Fitness of third chromosome homozygotes in Drosophila melanogaster

Mortimer, A. Martin and Shaw, David S. Cytofluorimetric evidence for meiosis in gametangial nuclei of Phytophthora drechsleri

No. 3 (June 1975)

Bremze, A. S., Sims, P. and Stacey, K. A. Trimethoprim-resistant mutants of $E$. coli $\mathrm{K} 12$ : preliminary genetic mapping

Brooker, R. J. and LovTIT, J. S. The replication of the chromosome of Pseudomonas aeruginosa strain 1. II. Sequential mutagenesis of synchronized cultures

Li, Wen-Hsiung and Nei, Masatoshi. Drift variances of heterozygosity and genetic distance in transient states

Bat, Jerzy, Bartnik, Ewa, Goryluk, Bożenna and Pientążek, Norman J. An easy way of obtaining Aspergillus nidulans haploids in the parasexual cycle using $N$-glycosyl poligungin

$\mathrm{D}_{\mathrm{A}}, \mathrm{A}$. W. and Cummrns, J. E. Evidence of a new kind of regulatory gene controlling expression of genes for morphogenesis during the cell cycle in Ustilago violacea

Charlesworth, Brian and Charlesworth, Deborah. An experiment on recombination load in Drosophila melanogaster

Dennison, Sheena and Baumberg, S. Unusual characteristics of the receptor for the $\mathrm{N}$ sex factor-specific filamentous phage IKe 
Cerdi-Olmeda, E. The genetics of Phycomyces blakesleeanus

Reeve, E. C. R. and Robertson, J.M. The characteristics of eleven mutants of R-factor R57 constitutive for tetracycline resistance, selected and tested in Escherichia coli $\mathrm{K} 12$

Онта, Томоко and Knгra, Мотоо. The effect of selected linked locus on heterozygosity of neutral alleles (the hitch-hiking effect)

Dixon, R., Cannon, F. C. and Postgate, J. R. Properties of the R factor R144drd3 in Klebsiella pneumoniae strain M5a 1

INDEX 


\section{GENETICAL RESEARCH}

VOLUME 25, NUMBER 3, JUNE 1975

\section{CONTENTS}

BREEZE, A. S., SIMS, P. and STACEY, K. A. Trimethoprim-resistant mutants of $E$. coli K12: preliminary genetic mapping

BROOKER, R. J. and LOUTIT, J. S. The replication of the chromosome of Pseudomonas aeruginosa strain 1. II. Sequential mutagenesis of synchronized cultures

LI, WEN-HSIUNG and NEI, MASATOSHI. Drift variances of heterozygosity and genetic distance in transient states

BAL, JERZY, BARTNIK, EWA, GORYLUK, BOŻENNA and PIENIÁżEK, Norman J. An easy way of obtaining Aspergillus nidulans haploids in the parasexual cycle using $N$-glycosyl polifungin

DAY, A. W. and симмгNs, J. E. Evidence for a new kind of regulatory gene controlling expression of genes for morphogenesis during the cell cycle in Ustilago violacea

CHARLESWORTH, BRIAN and CHARLESWORTH, DEBORAH. An experiment on recombination load in Drosophila melanogaster

DENNISON, SHEENA and BAUMBERG, S. Unusual characteristics of the receptor for the $\mathrm{N}$ sex factor-specific filamentous phage IKe

CERDÁ-OLMEDO, E. The genetics of Phycomyces blakesleeanus

REEVE, E. C. R. and ROBERTSON, J. M. The characteristics of eleven mutants of R-factor R57 constitutive for tetracycline resistance, selected and tested in Escherichia coli $\mathrm{K} 12$

онта, томоко and кгмива, мотоо. The effect of selected linked locus on heterozygosity of neutral alleles (the hitch-hiking effect)

Dixon, R., cannon, F. C. and Postgate, J. R. Properties of the R factor

$\mathrm{R} 144 d r d 3$ in Klebsiella pneumoniae strain M5a 1

IN D EX

Cambridge University Press, 1975

\section{CAMBRIDGE UNIVERSITY PRESS}

Bentley House, 200 Euston Road, London NW 1 2DB

32 East 57th Street, New York, N.Y.10022 